\title{
A LEI N..$^{\circ}$ 13.104/2015 (FEMINICÍDIO): SIMBOLISMO PENAL OU UMA QUESTÃO DE DIREITOS HUMANOS?
}

\section{LA LEY N. 13.104/2015 (FEMINICIDIO): ¿SIMBOLISMO PENAL O UNA CUESTIÓN DE DERECHOS HUMANOS?}

\author{
${ }^{1}$ Eduardo Daniel Lazarte Moron \\ ${ }^{2}$ Francisco Antonio Nieri Mattosinho
}

\begin{abstract}
RESUMO
O presente artigo discute as consequências legais e dogmáticas da Lei n. ${ }^{\circ}$ 13.104/2015 que acrescentou a qualificadora do feminicídio ao homicídio doloso. Em termos de direito comparado, fez-se uma análise das legislações no âmbito latino-americano em relação ao tema. Parte-se da função simbólica do direito penal para indagar se a alteração legislativa promovida constitui efetivamente uma reafirmação das normas internacionais em tema de direitos humanos ou é mais um exemplo do denominado simbolismo penal. A pesquisa foi eminentemente bibliográfica para concluir que o Simbolismo Penal pode ser superado enquanto realidade normativa desde que se tenha como parâmetro a ordem constitucional e supranacional nas quais se funda o ordenamento penal brasileiro.
\end{abstract}

Palavras-chave: Feminicídio, Simbolismo penal, Direitos humanos

\section{RESUMEN}

El presente artículo discute las consequencias legales y dogmáticas de la Lei n. ${ }^{\circ}$ 13.104/2015 que añadio la calificadora del feminicídio al homicídio doloso. En términos de derecho comparado analisamos las leyes en el contexto latino-americano. Partimos de la función simbólica del derecho penal para investigar si la alteración legislativa efectuada constituye en verdad una reafirmación de las normas internacionales en tema de derechos humanos o mas un ejemplo del simbolismo penal. La investigación fue bibliográfica para concluir que el simbolismo penal puede ser superado como realidad normativa desde que se utilize como padrón la orden constitucional y supranacional en las cuales se fundamenta la orden jurídica penal brasileña.

Palabras-claves: Femenicidio, Simbolismo penal, Derechos humanos

\footnotetext{
${ }^{1}$ Doutorando em Direito Constitucional pela Universidade de Fortaleza- UNIFOR, Ceará (Brasil). Professor de Direito Penal pela Faculdades Cathedral de Ensino Superior - FACES, Roraima (Brasil). E-mail: lazla8@hotmail.com

${ }^{2}$ Mestrando em Mestrado em Ciências Jurídicas pela Universidade Estadual do Norte do Paraná - UENP, Paraná (Brasil). Analista de Promotoria pelo Ministério Público do Estado de São Paulo - MPSP, São Paulo (Brasil) E-mail: mattosinho_17@hotmail.com
} 


\section{INTRODUÇÃO}

O Estado é visto como um instrumento masculino de dominação, sendo necessárias mudanças estruturais, bem como políticas e direitos especiais em razão do gênero para “empoderar" as mulheres ${ }^{1}$.

A condição jurídica da mulher em várias partes do mundo era lamentável. É bem verdade que vários problemas ainda persistem, mesmo com as ações patrocinadas no plano das Nações Unidas. Todavia, muitos Estados têm desenvolvido legislações no plano doméstico no sentido de fomentar a proteção da mulher.

A Comissão Parlamentar Mista de Inquérito instalada em junho de 2013 para investigar a violência contra a mulher registrou que 44 (quarenta e quatro mil) mulheres entre 2000 e 2010 foram vítima de feminicídio, sendo 41\% (quarenta e um) desses crimes ocorridos nas suas próprias casas por companheiros ou ex-companheiros.

A Convenção sobre a eliminação de todas as formas de discriminação contra a mulher, adotada em 1979, registra grande preocupação de a mulher continuar sendo vítima de abusos, constrangimentos e discriminações. Dessa forma, a discriminação feminina constituise em obstáculo para o aumento do bem-estar da sociedade e da família, dificultando o desenvolvimento das potencialidades da mulher para prestação de serviços a seu país e à humanidade. A Convenção veda, portanto, qualquer tipo de discriminação contra a mulher, objetivando o desenvolvimento de políticas públicas voltadas para a mulher.

No âmbito do sistema regional de proteção dos direitos humanos, a Convenção Interamericana para Prevenir, Punir e Erradicar a Violência contra a Mulher (Convenção de Belém do Pará), foi adotada em 9 de junho de 1994, no 24º Período Ordinário de Sessões da Assembleia Geral a Organização dos Estados Americanos (OEA). Esse tratado foi ratificado pelo Brasil na mesma data de sua adoção e o Congresso Nacional o aprovou por meio do Decreto Legislativo $\mathrm{n}^{\circ} 107$, de 31 de agosto de 1995. O governo brasileiro depositou a carta de ratificação em 27 de novembro de 1995, data em que a Convenção começou a vigorar para o Brasil. Por fim, a promulgação se deu com o Decreto $n^{\circ} 1.973$, de $1^{\circ}$ de agosto de 1996.

O primeiro passo do legislador para combater a violência contra as mulheres se deu com a edição da Lei n. ${ }^{\circ}$ 11.340/2006, conhecida como Lei Maria da Penha. Sua importância deriva do contexto gerador de sua formulação, colocando Maria da Penha como símbolo da luta da mulher contra a violência doméstica, haja vista ter sido vítima de duas tentativas de

\footnotetext{
${ }^{1}$ ALIMENA, Carla Marrone. A tentativa do impossível: Feminismos e criminologias. Rio de Janeiro: Lumen Juris, 2010, p. 72.
} 
feminicídio cometidas por seu então companheiro, em 1983, uma com disparo de tiros enquanto ela dormia e outro com a tentativa de eletrocutá-la, além das inúmeras agressões sofridas, que resultaram em estado de paraplegia.

Mesmo com a condenação pelo Tribunal do Júri, o agressor valeu-se de sucessivos recursos para se manter em liberdade, o que levou as entidades CEJIL-Brasil (Centro para Justiça e o Direito Internacional) e CLADEM-Brasil (Comitê Latino-Americano e do Caribe para a Defesa dos Direitos da Mulher) a apresentar uma petição à Comissão Interamericana de Direitos Humanos (CIDH), resultando, em 2001, na edição de recomendações pela Comissão para que o Estado brasileiro, dentre outras:

Prosseguir e intensificar o processo de reforma que evite a tolerância estatal e o tratamento discriminatório com respeito à violência doméstica contra mulheres no Brasil. A Comissão recomenda particularmente o seguinte:

a) Medidas de capacitação e sensibilização dos funcionários judiciais e policiais especializados para que compreendam a importância de não tolerar a violência doméstica;

b) Simplificar os procedimentos judiciais penais a fim de que possa ser reduzido o tempo processual, sem afetar os direitos e garantias de devido processo;

c) $\mathrm{O}$ estabelecimento de formas alternativas às judiciais, rápidas e efetivas de solução de conflitos intrafamiliares, bem como de sensibilização com respeito à sua gravidade e às consequências penais que gera;

d) Multiplicar o número de delegacias policiais especiais para a defesa dos direitos da mulher e dotá-las dos recursos especiais necessários à efetiva tramitação e investigação de todas as denúncias de violência doméstica, bem como prestar apoio ao Ministério Público na preparação de seus informes judiciais. ${ }^{2}$

A Lei Maria da Penha acarretou modificações na compreensão que a violência contra as mulheres não deve ser tratada de maneira isolada, como um problema apenas de justiça criminal, prevendo a possibilidade de implantação de medidas de caráter preventivo e educacionais para coibir a violência e a discriminação baseado no gênero ${ }^{3}$.

É oportuno sublinhar que, apesar dos avanços no combate à violência doméstica e familiar contra a mulher, as leis editadas não foram suficientes para eliminar a discriminação e a violência contra elas perpetradas.

$\mathrm{Na}$ atual conjuntura brasileira, o debate dos problemas ligados ao controle social penal, entre os quais destacamos a violência doméstica e familiar contra a mulher e a violação dos direitos humanos, integram a agenda do Poder Legislativo e alimentam no dia a dia os meios de comunicação em massa.

${ }^{2}$ CIDH. Relatório Anual 2000. Relatório no 54/01. Caso 12.051. Maria da Penha Maia Fernandes. Brasil. 4 de abril de 2001. Disponível em: http://www.cidh.org/annualrep/2000port/12051.htm. Acessado em 20/07/2015.

${ }^{3}$ ALIMENA, Carla Marrone. Op. cit, p. 72. 


\section{CONCEITO DE FEMINICÍDIO}

A legislação brasileira nutriu, em seu bojo, essência patriarcalista, alçando o homem como centro e a mulher como objeto de proteção ${ }^{4}$. O sexo é uma das variáveis que mais influem na vida pessoal dos indivíduos. Como é bem fácil de compreender, ser homem ou mulher afeta opções que uma pessoa pode fazer em sua vida e também sua ocupação cotidiana, assim como os sistemas de controle informal a que é submetida. Todavia, a variável que correlaciona de forma mais sólida com a criminalidade é o sexo ${ }^{5}$.

Não podemos confundir as expressões feminicídio e femicídio. Esta consiste na ação de matar uma mulher, enquanto aquela é a supressão da vida humana de uma mulher por razões de condição de sexo feminino, isto é, exige uma motivação especial.

O código penal brasileiro tratou do feminicídio com as alterações realizadas por meio da Lei $n^{\circ} 13.104$, de 10 de março de 2015.

O feminicídio pode ser definido como uma qualificadora do crime de homicídio motivada pelo ódio contra as mulheres, caracterizado por circunstâncias específicas em que o pertencimento da mulher ao sexo feminino é central na prática do delito.

Entre essas circunstâncias estão incluídos: os assassinatos em contexto de violência doméstica/familiar, e o menosprezo ou discriminação à condição de mulher. Os crimes que caracterizam a qualificadora do feminicídio reportam, no campo simbólico, a destruição da identidade da vítima e de sua condição de mulher.

Também conhecido como "crime fétido", vem a ser uma expressão que vai além da compreensão daquilo designado por misoginia, originando um ambiente de pavor na mulher, gerando o acossamento e sua morte. Compreendem as agressões físicas e da psique ${ }^{6}$, tais como o espancamento, suplício, estupro, escravidão, perseguição sexual, mutilação genital, intervenções ginecológicas imotivadas, impedimento do aborto e da contracepção, esterilização forçada, e outros atos dolosos que geram morte da mulher ${ }^{7}$.

\footnotetext{
4 PEGORER, Mayara Alice Souza. De Amélia a Maria da Penha: a evolução da legislação penal e das construções jurídicas na proteção dos direitos sexuais da mulher. Argumenta: Revista do Programa de Mestrado em Ciência Jurídica, da Universidade Estadual do Norte do Paraná - UENP. N. 19 (julho/dezembro) Jacarezinho, 2013. ISSN 1676-2800, p. 67.

5 SERRANO MAÍllo, Alfonso \& PRADO, Luiz Regis. Curso de criminologia. 2. ${ }^{\text {a }}$ ed. São Paulo: Editora Revista dos Tribunais, 2013.

${ }^{6}$ EMENTA: APELAÇÃO CRIMINAL - VIOLÊNCIA DOMÉSTICA - PEDIDO DE FIXAÇÃO DE MEDIDAS PROTETIVAS DIVERSAS DAQUELAS FIXADAS PELO JUÍZO "A QUO" - POSSIBILIDADE NECESSIDADE DE SE COIBIR A VIOLÊNCIA FÍSICA, MORAL E/OU PSICOLÓGICA PRATICADA PELO AGRESSOR CONTRA A OFENDIDA. Presentes provas de que o apelado vem atentando, constantemente, contra as integridades física, moral e psicológica de sua ex-companheira, a imposição de medidas protetivas de urgência mais gravosas, se afigura necessária. (TJMG - Apelação Criminal 1.0418.14.002755-2/001, Relator(a): Des.(a) Cássio Salomé , 7ª CÂMARA CRIMINAL, julgamento em 25/06/2015, publicação da súmula em 03/07/2015)

${ }^{7}$ http://www.impetus.com.br/artigo/876/estudo-completo-do-feminicidio. Acesso em 12 de julho de 2015.
} 


\section{O FEMINICÍDIO NO CONTEXTO LATINO-AMERICANO}

$\mathrm{Na}$ América Latina, a penalização do feminicídio é recente. Por diferentes instrumentos, quinze países da região criaram formas de coibir e punir esse crime, seja tipificando o feminicídio ou femicídio, por meio da reforma do código penal vigente, ou ainda estabelecendo agravantes para o assassinato de mulheres por motivação de gênero. Costa Rica foi o primeiro país a criminalizar o feminicídio ${ }^{8}$ em sua lei penal, em maio de $2007^{9}$.

A República de El Salvador por meio da Lei n 520, de 25 de novembro de 2010 (Lei especial integral para uma vida livre de violência para as mulheres) estabeleceu a mesma pena de prisão prevista na Lei da Costa Rica.

Por sua vez na América do Sul podemos ilustrar o tema, apontando o Código Penal argentino, que em seu artigo 80 dispõe:

ARTíCULO 80. - Se impondrá reclusión perpetua o prisión perpetua, pudiendo aplicarse lo dispuesto en el artículo 52, al que matare:

$1^{\circ} \mathrm{A}$ su ascendiente, descendiente o cónyuge, sabiendo que lo son.

Semelhante redação é encontrada no Código Penal boliviano, em seu artigo 252, com a seguinte redação:

ARTICULO 252 (Asesinato) - Será sancionado con la pena de presidio de treinta años, sin derecho a indulto el que matare:

$1^{\circ}$ A sus descendientes o cónyuge, o conviviente, sabiendo que lo son.

O Código Penal Chileno em seu art. 390 tipificou de maneira expressa o femicídio e não o feminicídio, como desdobramento do crime de homicídio.

1. Del homicidio

Art. 390. El que, conociendo las relaciones que los ligan, mate a su padre, madre o hijo, o cualquier otro de sus ascendientes o descendientes o a quien es o ha sido su cónyuge o su conviviente, será castigado, como parricida, con la pena de presidio mayor en su grado máximo a presidio perpetuo calificado.

Si la víctima del delito descrito en el inciso precedente es o ha sido la cónyuge o la conviviente de su autor, el delito tendrá el nombre de femicidio.

O Código Penal Peruano tipificou o crime de parricídio:

Artículo 107.- Parricidio

El que, a sabiendas, mata a su ascendiente, descendiente, natural o adoptivo, o a su cónyuge o concubino, será reprimido con pena privativa de libertad no menor de quince años.

O Código Penal peruano, em seu artigo 107, tipifica de forma autônoma o crime de parricídio em que a vítima pode ser o cônjuge, sem exigir uma motivação especial quanto à

\footnotetext{
${ }^{8}$ Lei n. 8.589 de 25 de abril de 2007 (Lei de Penalização de Violência contra as mulheres) Prisão de 20 a 35 anos.

9 http://www.compromissoeatitude.org.br/legislacoes-da-america-latina-que-penalizam-o-feminicidio/. Acesso em 12 de julho de 2015.
} 
condição do sexo feminino, não configurando o feminicídio e nem o femicídio. O mesmo código também não relacionou o feminicídio como qualificadora do homicídio.

Em termos gerais os códigos penais da América do Sul citados, apenas se referem ao cônjuge como vítima, não exigindo motivação especial e muito menos que seja mulher, afastando os conceitos de feminicídio e femicídio.

Como inovação em relação ao tema, e tratando efetivamente do feminicídio na América do Sul, tem-se o Código penal colombiano, que assim o disciplinou:

\section{CAPÍTULO II. \\ DEL HOMICIDIO \\ Artículo 103. Homicidio. [Penas aumentadas por el artículo 14 de la ley 890 de 2004, a partir del 1o. de enero de 2005] El que matare a otro, incurrirá en prisión de doscientos ocho (208) a cuatrocientos cincuenta (450) meses. \\ Artículo 104. Circunstancias de agravación. [Penas aumentadas por el artículo 14 de la ley 890 de 2004] La pena será de cuatrocientos (400) a seiscientos (600) meses de prisión, si la conducta descrita en el artículo anterior se cometiere: \\ 1. [Modificado por el artículo 26 de la Ley 1257 de 2008] En los cónyuges o compañeros permanentes; en el padre y la madre de familia, aunque no convivan en un mismo hogar, en los ascendientes o descendientes de los anteriores y los hijos adoptivos; y en todas las demás personas que de manera permanente se hallaren integradas a la unidad doméstica. \\ 11. [Adicionado por el artículo 26 de la ley 1257 de 2008] Si se cometiere contra \\ una mujer por el hecho de ser mujer. (grifo nosso)}

O Código Penal colombiano é exemplo de redação mais detalhada a respeito do tema, em total conformidade com a definição de feminicídio, pois explicita o fim especial de agir do sujeito ativo, quando exige que o crime seja cometido pelo simples fato de a vítima ser mulher.

A melhor interpretação é que a expressão "pelo fato de ser mulher" é mais compatível com a definição do feminicídio, que é o assassinato em decorrência de conflitos de gênero, ou seja, pelo fato de ser mulher. O objetivo da lei é, assim, "garantir a investigação e a punição dos atos violentos cometidos contra mulheres por motivo de gênero e discriminação" ${ }^{\prime 10}$.

Na mesma linha, o Código penal brasileiro foi mais específico, tratando de fato do feminicídio.

\section{ASPECTOS CONTROVERSOS DA APLICAÇÃO DA LEI DO FEMINIĆ́DIO E SUA NATUREZA DE QUALIFICADORA}

O feminicídio não é um crime autônomo e sim um tipo penal derivado com um fim especial de agir. Será que somente a partir da edição da Lei n. ${ }^{\circ}$ 13.104/2015 é que o

\footnotetext{
${ }^{10} \mathrm{http} / / / \mathrm{m}$. operamundi.uol.com.br/conteudo/noticias/40944/com+punicao+de+ate+50+anos+lei+que+tipifica+o+ feminicidio+e+sancionada+na+colombia.shtml. Acesso em 12 de julho de 2015.
} 
feminicídio passou a qualificar o homicídio? Isso porque, se o homicídio é praticado contra a mulher por razões da condição de sexo feminino, essa situação poderia ser amoldada às qualificadoras de motivo torpe (art. 121, $\S 2^{\circ}$, I) ou fútil (art. 121, $\S 2^{\circ}$, II).

Motivo torpe, como previsto na Exposição de Motivos do Código Penal de 1940, é o motivo que suscita a aversão ou repugnância geral, como, por exemplo, a cupidez, a luxúria, o despeito da imoralidade contrariada, o prazer do mal. Luiz Regis Prado o define: "como sendo o motivo abjeto, indigno e desprezível, que repugna ao mais elementar sentimento ético. $\mathrm{O}$ motivo torpe provoca acentuada repulsa, sobretudo pela ausência de sensibilidade moral do executor"11.

O motivo fútil, também comentado naquela Exposição, é o motivo que, pela sua mínima importância, não é causa suficiente para o crime.

As qualificadoras do homicídio, previstas no $2^{\circ}{ }^{\circ}$ do artigo 121 do Código Penal, são classificadas em quatro categorias: qualificadoras relacionadas aos motivos do crime (inciso I e II), aos meios de execução (inciso III), aos modos de execução (inciso IV) e aos fins (inciso $\mathrm{V})$.

A qualificadora acrescentada pelo inciso VI refere-se aos motivos do crime e ao mesmo tempo à qualidade da vítima. Ela já estaria inserida no inciso I como exemplo de motivo torpe, o que, em tese, tornaria desnecessária a existência do inciso VI.

A motivação específica, por sua vez, não é novidade, considerando que, em razão de tratados internacionais, o Brasil inseriu o $§ 9 .^{\circ}$ no artigo 129 do Código Penal e editou a Lei n. ${ }^{\circ}$ $11.340 / 2006$.

A redação do inciso VI aponta:

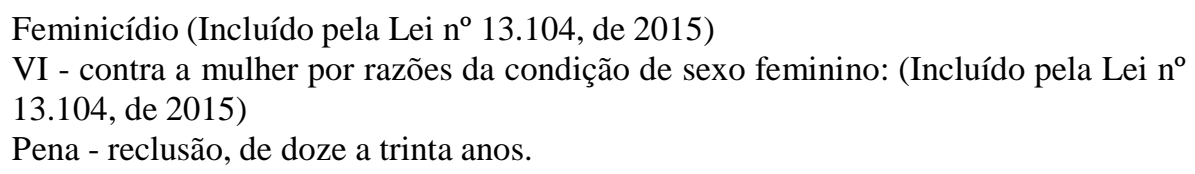

Destaque-se que nem sempre o homicídio doloso qualificado em que a mulher é vítima será considerado feminicídio. O feminicídio é um homicídio doloso qualificado contra a mulher por razões de condição de sexo feminino, em que somente pode figurar como sujeito passivo a mulher, não existindo a modalidade culposa. O julgamento desse crime compete ao Tribunal do Júri e não aos Juizados de Violência Doméstica.

A qualificadora exige, além do dolo genérico, que é a intenção de matar (animus necandi), um dolo específico, segundo Damásio de Jesus:

\footnotetext{
${ }^{11}$ PRADO, Luiz Regis. Curso de direito penal, volume 2: parte especial. 9. a ed. São Paulo: Editora Revista dos Tribunais, 2010, p.85.
} 
É a vontade de praticar o fato e produzir um fim especial (específico). Assim no homicídio, é suficiente o dolo genérico, uma vez que o tipo do art. 121 caput, não menciona nenhuma finalidade especial do sujeito; ele só quer somente matar a vítima, não matá-la para alguma coisa. ${ }^{12}$

O especial fim de agir, ou seja, elemento subjetivo específico do tipo que está para além do dolo, caracteriza crime de intenção. Fernando Capez define o delito de intenção: "como aquele em que o agente quer e persegue um resultado que não necessita ser alcançado de fato para a consumação do crime (tipos incongruentes)" ${ }^{13}$, isto é, um fim especial de agir pela condição do sexo feminino.

O legislador penal brasileiro sempre considerou as qualidades da vítima no crime de homicídio como causa de aumento de pena, conforme o disposto no artigo $121 \S 44^{\circ}$, parte final, em que a idade da vítima aumenta de 1/3 a pena do homicídio doloso.

O inciso VI do §2..$^{\circ}$ do artigo 121 não exige somente que o crime seja cometido contra a mulher, devendo a motivação do crime se fundar na condição do sexo feminino.

O próprio legislador fez questão de definir quando as razões de condição do sexo feminino estarão presentes, se utilizando da interpretação autêntica:

\section{§ 2o-A Considera-se que há razões de condição de sexo feminino quando o crime envolve: (Incluído pela Lei $\mathrm{n}^{\circ} 13.104$, de 2015) \\ I - violência doméstica e familiar; (Incluído pela Lei no 13.104, de 2015) \\ II - menosprezo ou discriminação à condição de mulher. (Incluído pela Lei $\mathrm{n}^{\circ}$ 13.104, de 2015)}

A noção de gênero pode ser entendida como construção sociocultural do masculino e do feminino, isto é, são atribuídos papéis diversos para homens e mulheres em sociedade, estabelecendo direitos e deveres, com estrutura diversificada e hierarquizada ${ }^{14}$.

O legislador fez questão de definir o que se considera razões de condição do sexo feminino, e no inciso I disciplinou quando o crime envolve violência doméstica e familiar.

O conceito de violência doméstica e familiar a ser utilizado é aquele previsto no artigo 5. ${ }^{\circ}$ da Lei n. ${ }^{\circ}$ 11.340/2006 que apresenta a interpretação autêntica do legislador sobre violência doméstica e familiar contra a mulher, sem prejuízo da utilização da interpretação sistemática, que consiste segundo Carlos Maximiliano: "No processo sistemático em comparar o dispositivo sujeito a exegese, com outros do mesmo repositório ou de leis diversas, mas referentes ao mesmo objeto" 15 e a interpretação teleológica:

Art. 5. Para os efeitos desta Lei, configura violência doméstica e familiar contra a mulher qualquer ação ou omissão baseada no gênero que lhe cause morte, lesão, sofrimento físico, sexual ou psicológico e dano moral ou patrimonial: (Vide Lei complementar $\mathrm{n}^{\circ} 150$, de 2015)

\footnotetext{
12 JESUS, Damásio de. Direito Penal, parte geral. 20ªed. São Paulo: Saraiva, 1997, 1997, p. 286.

${ }^{13}$ CAPEZ, Fernando. Curso de direito penal, volume I, parte geral. 16. ${ }^{\mathrm{e}} \mathrm{ed}$. São Paulo: Saraiva, 2012, p. 292.

${ }_{11}^{14}$ GUERRA, Sidney. Direitos humanos: curso elementar. São Paulo: Saraiva, 2013, p. 229.

${ }^{15}$ MAXIMILIANO, Carlos. Hermenêutica e aplicação do direito. 20 ${ }^{\mathrm{a}}$.ed. Rio de Janeiro: Forense, 2011, p. 104.
} 
I - no âmbito da unidade doméstica, compreendida como o espaço de convívio permanente de pessoas, com ou sem vínculo familiar, inclusive as esporadicamente agregadas;

II - no âmbito da família, compreendida como a comunidade formada por indivíduos que são ou se consideram aparentados, unidos por laços naturais, por afinidade ou por vontade expressa;

III - em qualquer relação íntima de afeto, na qual o agressor conviva ou tenha convivido com a ofendida, independentemente de coabitação.

Parágrafo único. As relações pessoais enunciadas neste artigo independem de orientação sexual.

Art. 7. ${ }^{\circ}$ São formas de violência doméstica e familiar contra a mulher, entre outras: I - a violência física, entendida como qualquer conduta que ofenda sua integridade ou saúde corporal;

II - a violência psicológica, entendida como qualquer conduta que lhe cause dano emocional e diminuição da auto-estima ou que lhe prejudique e perturbe o pleno desenvolvimento ou que vise degradar ou controlar suas ações, comportamentos, crenças e decisões, mediante ameaça, constrangimento, humilhação, manipulação, isolamento, vigilância constante, perseguição contumaz, insulto, chantagem, ridicularização, exploração e limitação do direito de ir e vir ou qualquer outro meio que lhe cause prejuízo à saúde psicológica e à autodeterminação;

III - a violência sexual, entendida como qualquer conduta que a constranja a presenciar, a manter ou a participar de relação sexual não desejada, mediante intimidação, ameaça, coação ou uso da força; que a induza a comercializar ou a utilizar, de qualquer modo, a sua sexualidade, que a impeça de usar qualquer método contraceptivo ou que a force ao matrimônio, à gravidez, ao aborto ou à prostituição, mediante coação, chantagem, suborno ou manipulação; ou que limite ou anule o exercício de seus direitos sexuais e reprodutivos;

IV - a violência patrimonial, entendida como qualquer conduta que configure retenção, subtração, destruição parcial ou total de seus objetos, instrumentos de trabalho, documentos pessoais, bens, valores e direitos ou recursos econômicos, incluindo os destinados a satisfazer suas necessidades;

$\mathrm{V}$ - a violência moral, entendida como qualquer conduta que configure calúnia, difamação ou injúria.

Por sua vez, o inciso II apresenta conceito subjetivo, constituindo um elemento normativo do tipo, que na ótica de Bittencourt: "São aqueles para cuja compreensão é insuficiente desenvolver uma atividade meramente cognitiva, devendo-se realizar uma atividade valorativa. São circunstâncias que não se limitam a descrever o natural, mas implicam um juízo de valor"16. Para a configuração da violência doméstica e familiar contra a mulher é indispensável que a vítima esteja em situação de hipossuficiência física ou econômica, em condição de vulnerabilidade, enfim, que a infração penal tenha como motivação a opressão à mulher ${ }^{17}$, pois o feminicídio visa tutelar uma situação de vulnerabilidade.

Acresceram-se três novas causas de aumento de pena exclusivas para o feminicídio:

$\S 7$ o A pena do feminicídio é aumentada de $1 / 3$ (um terço) até a metade se o crime for praticado: (Incluído pela Lei $n^{\circ} 13.104$, de 2015)

${ }^{16}$ BITENCOURT, Cezar Roberto. Tratado de Direito Penal: parte geral 1- 20. ${ }^{\text {a }}$ ed. São Paulo: Saraiva, 2014, p. 350

${ }^{17}$ LIMA, Renato Brasileiro de. Manual de Processo Penal. 2. aed. Salvador, BA: Editora Juspodium, 2014, p. 506. 
I - durante a gestação ou nos 3 (três) meses posteriores ao parto; (Incluído pela Lei $\mathrm{n}^{\mathrm{o}} 13.104$, de 2015)

II - contra pessoa menor de 14 (catorze) anos, maior de 60 (sessenta) anos ou com deficiência; (Incluído pela Lei ${ }^{\circ} 13.104$, de 2015)

III - na presença de descendente ou de ascendente da vítima. (Incluído pela Lei $\mathrm{n}^{\circ}$ 13.104, de 2015)

As citadas causas de aumento de pena serão aplicadas desde que tenham ingressado na esfera do conhecimento do sujeito ativo. Antes da existência da causa de aumento prevista no inciso I do $\$ 7 .^{\circ}$, havendo homicídio doloso qualificado por razões da condição de sexo feminino somente poderia ser tipificado no motivo torpe e estando a vítima grávida, incidiria a regra do concurso formal entre homicídio e aborto. Com a nova redação do §7. ${ }^{\circ}$ inciso I o sujeito ativo responde por homicídio doloso qualificado pelo feminicídio com a pena aumentada somente, em razão do princípio da especialidade.

Destaque-se que não devem incidir as agravantes do artigo 61 inciso II alíneas "h" e "f" do Código Penal, sob pena de bis in idem. Da mesma forma, não incide a causa de aumento do $\S 4 .^{\circ}$ do artigo 121, parte final.

A aplicação do inciso VI, por restringir direitos, demanda uma interpretação restritiva. Quando ocorre o homicídio de um transexual, evidentemente, que a motivação não será por razões de condição de sexo feminino, mas por intolerância ou discriminação, podendo ser abrangido pelo motivo torpe.

Por outro lado, utilizando o critério biológico o transexual não será considerado do sexo feminino, salvo quando submetido à cirurgia de mudança de sexo. Porém, pelo critério jurídico em razão da mudança judicial do prenome e do gênero, será considerado do sexo feminino. Nesse sentido esclarece Alimena: "Para participar como vítima do rito judicial previsto na Lei Maria da Penha, a princípio o sexo que consta no registro civil do indivíduo deve ser o feminino, o que possibilitaria a proteção de alguns transexuais". ${ }^{18}$ A discussão reflete mais do que uma simples questão de "mulher", passando a ser uma questão de gênero (opção sexual). De qualquer forma, por se tratar de norma penal incriminadora é vedado recorrer à analogia em malam partem, piorando a situação do réu.

O inciso III do $\S 7^{\circ}$ quando se refere à "presença” refere-se somente à presença física, devendo a interpretação, por restringir direitos, seguir o mesmo raciocínio restritivo.

Inexiste a possibilidade do homicídio doloso qualificado pelo feminicídio coexistir com as causas de diminuição de pena previstas no $§ 1 .^{\circ}$ do art. 121, denominadas como privilegiadoras, por ambas possuírem caráter subjetivo.

18 ALIMENA, Carla Marrone. A tentativa do impossível: Feminismos e criminologias. Rio de Janeiro: Lumen Juris, 2010, p. 81. 
Por fim, o legislador atentou-se para a necessidade de alteração da Lei dos Crimes Hediondos (Lei $\mathrm{n}^{\circ} 8.072 / 90$ ) e acrescentou o inciso VI no rol do artigo $1^{\circ}$, I.

\section{SIMBOLISMO PENAL}

Analisada a alteração legislativa, passa-se à discussão da necessidade da inclusão do feminicídio no ordenamento penal brasileiro. Nesse contexto, inicia-se a análise a partir da compreensão do que se denomina Simbolismo Penal ou Direito Penal Simbólico e seus desdobramentos dogmáticos acerca da nova qualificadora.

Compreender o sistema emergencial exige, além das indagações metajurídicas que necessariamente impõem respostas essenciais para visualizar seu funcionamento como um todo, a análise dos mecanismos legais que frutificam nesse ambiente cultural-político- normativo ${ }^{19}$.

O Direito Penal Simbólico é um fenômeno que nasce do sentimento de urgência que o Estado manifesta quando a aplicação indevida do Direito Penal, aliada às poucas políticas de prevenção da criminalidade, mostra consequências de efeitos eleitorais indesejáveis como o crime, a violência e todo o quadro social em que geralmente se inserem estes dois elementos $^{20}$.

A edição de leis, sem um critério rigoroso que garanta sua efetiva aplicação e coerência, acaba deturpando a função do direito penal, dando ensejo ao denominado Simbolismo Penal. Este simbolismo surge toda vez que leis são editadas como forma de resposta ao clamor social.

A qualificadora do feminicídio conduz a falsa percepção que antes da alteração legislativa, o homicídio de mulheres por questões de gênero não possuía tipificação no Código Penal, estando mulher desprotegida, o que não é verdade, considerando que a qualificadora do motivo torpe já supria essa omissão.

Nesse aspecto é que a função simbólica do direito penal, sustentada por Zaffaroni ${ }^{21}$ aplica-se ao feminicídio, pois o legislador fez questão de rotular de maneira expressa essa tese no Código Penal, com a finalidade de criar uma sensação de que a mulher a partir de agora estaria protegida de eventual crime.

\footnotetext{
${ }^{19}$ CHOUKR, Fauzi Hassan. Processo Penal de Emergência: Avaliação nos 20 anos de Vigência da Constituição de 1988. In Processo Penal e Democracia. Rio de Janeiro: Lumen Juris, 2009, p. 209.

${ }^{20} \mathrm{http}: / /$ sisnet.aduaneiras.com.br/lex/artigos/pdf/anti.pdf. Acesso em 17 de julho de 2015.

${ }^{21}$ ZAFFARONI, Eugenio Raúl. Manual de Direito Penal Brasileiro - Volume 1 - parte geral. 9a ed., rev. e atual. São Paulo: Editora Revista dos Tribunais, 2011. pp. 107-108.
} 
O Simbolismo Penal cumpre, obviamente, determinada missão dentro da sistemática criminal, não solucionando os problemas sociais de criminalidade, mas visando acalmá-la:

Digo simbólico porque a mim me parece claro que o legislador, ao submeter determinados comportamentos à normatização penal, não pretende, propriamente, preveni-los ou mesmo reprimi-los, mas tão-só infundir e difundir, na comunidade, uma só impressão - e uma falsa impressão - de segurança jurídica. Quer-se, enfim, por meio de uma repressão puramente retórica, produzir, na opinião pública, uma só impressão tranquilizadora de um legislador atento decidido ${ }^{22}$.

Destacam-se algumas normas penais para análise desse sistema: Lei n. ${ }^{\circ}$ 8.072/90 (Lei dos Crimes Hediondos), Lei n. ${ }^{\circ}$ 9.613/98 (Lei de Lavagem de Capitais), Lei n. ${ }^{\circ}$ 12.850/2013 (Organização Criminosa).

O sistema repressivo foi mais uma vez chamado a assumir a função de controle social, podendo causar a falsa impressão na população que, com a tipificação do feminicídio e sua inclusão no rol dos crimes hediondos, tem-se a via definitiva de solução desse grave problema.

Algumas características podem retratar essa visão do direito penal: o emprego do sistema penal numa visão promocional, pela qual ele é visto como o primeiro instrumento de regulação social; a transformação do sistema penal como um instrumento de política de governo e a profunda influência midiática na utilização do direito penal máximo como instrumento de controle social.

Pode-se, assim, afirmar que o simbolismo penal, geralmente, se apresenta através de propostas que visam a se aproveitar do medo e da sensação de insegurança. Nesse sentido, o propósito do legislador não é a real proteção dos bens jurídicos atingidos pelo delito, mas uma forma de adular a população, dizendo o que ela quer ouvir, fazendo o que ela deseja que se faça, mesmo que isso não surta qualquer efeito na diminuição da criminalidade e da violência ${ }^{23}$.

O Direito Penal de viés simbólico utiliza-se do medo e da sensação de insegurança da população. Ao invés de criar normas que realmente protejam os bens jurídicos considerados essenciais para a vida em sociedade, o legislador preocupa-se tão somente em criar uma falsa atmosfera de tranquilidade, gerando a sensação de que a criminalidade encontra-se sob controle ${ }^{24}$.

\footnotetext{
${ }^{22}$ QUEIROZ, Paulo. Sobre a função do juiz criminal na vigência de um direito penal simbólico. Boletim IBCCRIM. São Paulo, n. 74, p. 09, jan. 1999.

${ }^{23} \mathrm{http} / / / \mathrm{www}$. ambito-juridico.com.br/site/?n_link=revista_artigos_leitura\&artigo_id=12216\&revista_caderno=3. Acesso em 17 de julho de 2015.

${ }^{24} \mathrm{http}$ ://pedrosidi.jusbrasil.com.br/artigos/121942588/funcao-simbolica-do-direito-penal. Acesso em 17 de julho de 2015.
} 
A alteração legislativa, ao privilegiar aspectos punitivos, se aproximou de outros países em relação à eficácia simbólica do direito penal. O esforço do legislador em modificar o Código Penal nesse tema parece se apoiar muito mais numa crença na eficácia simbólica que essa qualificadora pode ter nos agressores.

De forma geral, não se pode dizer ter havido um debate público sobre o amplo movimento reformista de cunho emergencial. Nem mesmo a própria percepção da criação desse subsistema não tem tido a atenção necessária por parte da doutrina penal brasileira.

Conforme foi destacado nos capítulos anteriores o feminicídio sempre foi crime qualificado pelo motivo torpe. Ocorre que o legislador, por uma questão de simbolismo e por querer disciplinar toda e qualquer matéria, pois na sua visão se não está escrito no Código Penal determinada expressão não é crime, num nítido exemplo de legislação penal simbólica e passando a ilusão que está atento aos problemas sociais, elabora leis identificativas, isto é, identifica um problema social naquela coletividade e positiva a solução para aquele problema.

Surge a lei reativa como consequência da lei identificativa, como se a lei fosse encerrar o problema da violência doméstica e familiar contra a mulher.

A violência contra a mulher precisa ser combatida. Porém, somente a elaboração de leis nesse sentido não resolve o problema de criminalidade social. De fato houve, após a edição da Lei Maria da Penha, uma diminuição da violência contra a mulher, mas a questão deve ser enfrentada com fiscalização e medidas preventivas de proteção à mulher, reafirmando o princípio da dignidade da pessoa humana.

A opção do legislador por reformas setoriais ou pontuais, a exemplo da Lei n. ${ }^{\circ}$ 13.104/2015 (Feminicídio), pode não satisfazer as necessidades da sociedade, porém, se efetivadas em conformidade com a Constituição e com as Convenções Internacionais sobre Direitos Humanos, são válidas e convergentes.

A multiplicidade de desejos e anseios das mulheres em situação de violência são tão variáveis e díspares que se torna esperada a incompatibilidade de uma forma de resposta situada unicamente na pena.

O Simbolismo Penal pode ser superado enquanto realidade normativa desde que se tenha como parâmetro a ordem constitucional e supranacional nas quais se funda o ordenamento penal brasileiro.

\section{UMA QUESTÃO DE DIREITOS HUMANOS}

Enfrentada a questão da inclusão do feminicídio a partir do prisma crítico do Simbolismo Penal, resta ponderar se a alteração legislativa não é fruto dos compromissos 
internacionais assumidos pelo Brasil perante o Sistema Interamericano de Direitos Humanos e se os relatórios da Comissão Interamericana e a jurisprudência da Corte Interamericana não apontam para a necessidade de os Estados adotarem medidas legislativas para enfrentar o problema da discriminação baseada em questões de gênero que, em casos extremos, resulta na prática de homicídios em razão desses motivos.

Inicialmente, deve-se lembrar que a República Federativa do Brasil ratificou a Convenção Americana sobre Direitos Humanos (CADH) em 1992, tendo sido promulgada internamente pelo Decreto $\mathrm{n}^{\circ} 678$, de 6 de novembro do mesmo ano. A CADH foi internalizada no ordenamento jurídico brasileiro antes da aprovação da Emenda Constitucional $\mathrm{n}^{\circ}$ 45, de 30 de dezembro de 2004, que acrescentou o $\S 3^{\circ}$ ao artigo $5^{\circ}$ da Constituição Federal de 1988 cuja redação prevê: "os tratados e convenções internacionais sobre direitos humanos que forem aprovados, em cada Casa do Congresso Nacional, em dois turnos, por três quintos dos votos dos respectivos membros, serão equivalentes às emendas constitucionais”.

Todavia, em 3 de dezembro de 2008, o Supremo Tribunal Federal, no julgamento do Recurso Extraordinário n ${ }^{\circ}$ 349.703/RS, entendeu que, desde a adesão do Brasil, sem qualquer reserva, ao Pacto Internacional dos Direitos Civis e Políticos (art. 11) e à CADH (art. $\left.7^{\circ}, 7\right)$, ambos no ano de 1992, não há mais base legal para prisão civil do depositário infiel, pois o caráter especial desses diplomas internacionais sobre direitos humanos lhes reserva lugar específico no ordenamento jurídico, estando abaixo da Constituição, porém acima da legislação interna. ${ }^{25}$

Com esse entendimento, cinge a discussão a respeito de três possíveis posições hierárquicas desses tratados, como comenta Marcelo Novelino:

\begin{abstract}
Os tratados internacionais passaram a ter três hierarquias distintas: os tratados e convenções internacionais de direitos humanos, aprovados em cada Casa do Congresso Nacional, em dois turnos, por três quintos dos votos dos respectivos membros, serão equivalentes às emendas constitucionais $\left(\mathrm{CF}\right.$, art. $\left.5^{\circ}, \S^{\circ}\right)$; os tratados internacionais de direitos humanos, aprovados pelo procedimento ordinário (CF, art. 47), terão status supralegal, situando-se abaixo da Constituição e acima da legislação ordinária; os tratados e convenções internacionais que não versem sobre direitos humanos ingressarão no ordenamento jurídico brasileiro com força de lei ordinária. $^{26}$
\end{abstract}

No atual cenário, somente a Convenção Internacional sobre os Direitos das Pessoas com Deficiência e seu Protocolo Facultativo, assinados em Nova York, em 30 de março de 2007, aprovado por meio do Decreto Legislativo n 186 , de 9 de julho de 2008, e promulgado

25 BRASIL. Supremo Tribunal Federal. RE 349703, Relator(a): Min. CARLOS BRITTO, Relator(a) p/ Acórdão: Min. GILMAR MENDES, Tribunal Pleno, julgado em 03/12/2008, DJe-104 DIVULG 04-06-2009 PUBLIC 05-06-2009 EMENT VOL-02363-04 PP-00675.

${ }^{26}$ NOVELINO, Marcelo. Direito Constitucional. 6. ed. Rio de Janeiro: Forense, 2012, p. 472. 
pelo Decreto n ${ }^{\circ} 6.949$, de 25 de agosto de 2009, foi submetido ao procedimento estabelecido pelo art. $5^{\circ}, \S 3^{\circ}$. Assim, seguindo o precedente estabelecido pelo STF, somente esse diploma internacional teria equivalência à emenda constitucional.

Por sua vez, a doutrina já se posicionava, e ainda o faz, no sentido de que a inovação trazida pelo $\S 3^{\circ}$, do art. $5^{\circ}$, não se apresenta como novel conquista para os tratados internacionais sobre direitos humanos. Entende, na verdade, que a EC no 45/04 criou procedimento formal mais rígido para que os tratados de direitos humanos ingressem no ordenamento com hierarquia constitucional e manteve a equivocada visão da natureza supralegal dos diplomas internacionais. $^{27}$

Defendem os internacionalistas que os tratados internacionais sobre direitos humanos ratificados pelo Brasil são diretamente incorporados com status constitucional por força do art. $5^{\circ}, \S 2^{\circ}$, da $\mathrm{CF} / 88$, previsto desde a redação original, pois esse dispositivo reza que "os direitos e garantias expressos nesta Constituição não excluem outros decorrentes do regime e dos princípios por ela adotados, ou dos tratados internacionais em que a República Federativa do Brasil seja parte". Não bastasse isso, segundo o artigo $4^{\circ}$, II, da Constituição Federal, a República Federativa do Brasil rege-se nas suas relações internacionais pelo princípio da prevalência dos direitos humanos. Logo, a exigência formal de aprovação dos tratados por quórum qualificado, em dois turnos, nas duas Casas do Congresso Nacional, somente inovou ao criar duas figuras de tratados sobre direitos humanos, nas palavras de Flávia Piovesan:

Vale dizer, com o advento do $\S 3^{\circ}$, do art. $5^{\circ}$, surgem duas categorias de tratados
internacionais de proteção de direitos humanos: a) os materialmente constitucionais;
e b) os material e formalmente constitucionais. Frise-se: todos os tratados
internacionais de direitos humanos são materialmente constitucionais, por força do
$\S 2^{\circ}$, do art. $5^{\circ}$. Para além de serem materialmente constitucionais, poderão, a partir
do $\$ 3^{\circ}$ do mesmo dispositivo, acrescer a qualidade de formalmente constitucionais,
equiparando-se às emendas à Constituição, no âmbito formal. ${ }^{28}$

Assim, entendemos que a $\mathrm{CADH}$, por sua internalização anterior à previsão contida no $\S 3^{\circ}$ do art. $5^{\circ}$, foi diretamente assimilada pela ordem constitucional brasileira, por força do art. $5^{\circ}, \S 2^{\circ}$, detendo status constitucional e fazendo parte do bloco de constitucionalidade a ser observado e aplicado. A nosso ver, qualquer compreensão restritiva sobre a hierarquia constitucional dos tratados internacionais não submetidos ao procedimento formal de aprovação pelas Casas do Congresso implica em ofensa à força normativa da Constituição e em violação ao princípio da vedação do retrocesso.

\footnotetext{
${ }^{27}$ SARLET, Ingo Wolfgang. A eficácia dos direitos fundamentais. 11. Ed. ver. Atual. Porto Alegre: Livraria do Advogado Editora, 2012, p. 81. MELLO, Celso de Albuquerque. O parágrafo $2^{o}$ do art. $5^{\circ}$ da Constituição Federal in TORRES, Ricardo Lobo (org.). Teoria dos direitos fundamentais. Rio de Janeiro: Renovar, p. 25. PIOVESAN, Flávia. Direitos humanos e direito constitucional internacional. 14. Ed. ver. E atual. São Paulo: Saraiva, 2013, p. 113-162.

${ }^{28}$ Direitos humanos e o direito constitucional internacional. 14. Ed., rev. e atual. São Paulo: Saraiva, p. 145.
} 
Nesse sentido são as palavras de Vladimir Brega Filho:

Percebe-se, portanto, que a força normativa da constituição exige do intérprete um compromisso com a concretização de direitos estabelecidos em uma Constituição, sob pena de se estar descumprindo a ordem constitucional e também se enfraquecendo a sua força normativa. Conclui-se, portanto, que toda e qualquer interpretação da constituição deve ter como objetivo a concretização dos direitos nela assegurados. ${ }^{29}$

Quando da primeira condenação do Estado brasileiro pela Corte Interamericana de Direitos Humanos, no Caso Damião Ximenes, o juiz brasileiro daquele Tribunal, A. A. Cançado Trindade, em seu voto separado, teceu críticas ao $\$ 3^{\circ}$ :

(...) mal concebido, mal redigido e mal formulado, representa um lamentável retrocesso em relação ao modelo aberto consagrado pelo parágrafo $2^{\circ}$ do art. $5^{\circ}$ da Constituição Federal de $1988 .^{30}$

André de Carvalho Ramos despende esforços para que o $\$ 3^{\circ}$ não seja visto como inconstitucional:

\begin{abstract}
Agora, entendemos ser inegável o estatuto diferenciado dos tratados internacionais de direitos humanos, em face do disposto especialmente no art. $1^{\circ}$, caput, e inciso III (estabelecimento do Estado Democrático de Direito e consagração da dignidade humana como fundamento da República), e ainda em face do art. $5^{\circ}, \S 2^{\circ}$. Assim, os tratados de direitos humanos possuem natureza constitucional. Contudo, para que o rito especial do art. $5^{\circ}, \S 3^{\circ}$, não seja considerado um retrocesso e mantendo a premissa (todos os tratados de direitos humanos são equiparados a normas constitucionais), temos que o uso do rito especial do art. $5^{\circ}, \S 3^{\circ}$, faz nascer a exigência de idêntico quórum para sua denúncia, caso essa seja permitida pelo próprio tratado. $^{31}$
\end{abstract}

Assim posta a questão hierárquica da $\mathrm{CADH}$, verifica-se que a proteção dos direitos humanos nela prevista é coadjuvante e complementar da que oferece o direito interno dos seus Estados-partes. Tal proteção significa que não se retira dos Estados a competência primária de amparar e proteger os direitos das pessoas sujeitas à sua jurisdição, mas que, nos casos de falta de amparo ou de proteção aquém da necessária, pode o sistema interamericano atuar, concorrendo para o objetivo comum de proteger determinado direito que o Estado não garantiu ou preservou menos do que deveria. ${ }^{32}$

Na parte I (Deveres dos Estados e Direitos Protegidos), Capítulo I (Enumeração dos Deveres), os dois primeiros artigos da CADH preveem a obrigação dos Estados-partes de respeitar os direitos nela contidos $\left(\operatorname{art} .1^{\circ}\right.$ ) e o dever de adotar as necessárias disposições de

\footnotetext{
${ }^{29}$ BREGA FILHO, Vladimir. Proibição do retrocesso social: o estado da arte em Portugal e no Brasil in Argumenta: Revista do Programa de Mestrado em Ciência Jurídica, da Universidade Estadual do Norte do Paraná - UENP. N. 19 (julho/dezembro) - Jacarezinho, 2013, p. 107.

30 Corte Interamericana de Direitos Humanos. Caso Damião Ximenes Lopes Vs. Brasil. Voto Separado do Juiz A. A. Cançado Trindade, $\$ \S 30-31$.

31 RAMOS, André de Carvalho. Teoria geral dos direitos humanos na ordem internacional. - 4. Ed. - São Paulo: Saraiva, 2014, p. 281.

32 MAZZUOLI, Valerio de Oliveira. Os sistemas de proteção dos direitos humanos. Valerio Mazzuoli; corrdenação Alice Biachini, Luiz Flávio Gomes, William Terra de Oliveira. - São Paulo: Editora Revista dos Tribunais, 2011. - (Direito e ciências afins; v. 9), p. 21.
} 
direito interno para tornar efetivos os direitos e as liberdades mencionados no $\operatorname{art} .1^{\circ}$, caso ainda não as tenham garantido por disposições legislativas ou de outra natureza (art. $2^{\circ}$ ).

A mesma premissa pode ser aplicada à Convenção Interamericana para Prevenir, Punir e Erradicar a Violência contra a Mulher (Convenção de Belém do Pará). Em sua parte preambular, a Convenção dispõe que os Estados que dela fazem parte:

RECONHECENDO que o respeito irrestrito aos direitos humanos foi consagrado na Declaração Americana dos Direitos e Deveres do Homem e na Declaração Universal dos Direitos Humanos e reafirmado em outros instrumentos internacionais e regionais;

AFIRMANDO que a violência contra a mulher constitui violação dos direitos humanos e liberdades fundamentais e limita total ou parcialmente a observância, gozo e exercício de tais direitos e liberdades;

PREOCUPADOS por que a violência contra a mulher constitui ofensa contra a dignidade humana e é manifestação das relações de poder historicamente desiguais entre mulheres e homens;

RECORDANDO a Declaração para a Erradicação da Violência contra a Mulher, aprovada na Vigésima Quinta Assembléia de Delegadas da Comissão Interamericana de Mulheres, e afirmando que a violência contra a mulher permeia todos os setores da sociedade, independentemente de classe, raça ou grupo étnico, renda, cultura, nível educacional, idade ou religião, e afeta negativamente suas próprias bases;

CONVENCIDOS de que a eliminação da violência contra a mulher é condição indispensável para seu desenvolvimento individual e social e sua plena e igualitária participação em todas as esferas de vida; e

CONVENCIDOS de que a adoção de uma convenção para prevenir, punir e erradicar todas as formas de violência contra a mulher, no âmbito da Organização dos Estados Americanos, constitui positiva contribuição no sentido de proteger os direitos da mulher e eliminar as situações de violência contra ela,

Convieram em estabelecer as regras internacionais de proteção em favor da mulher.

$\mathrm{O}$ art. $7^{\circ}$, da Convenção de Belém do Pará apresenta as medidas que os Estados-parte se comprometem a adotar, dentre elas: agir com o devido zelo para prevenir, investigar e punir a violência contra a mulher e incorporar na sua legislação interna normas penais, civis, administrativas e de outra natureza, que sejam necessárias para prevenir, punir e erradicar a violência contra a mulher, bem como adotar as medidas administrativas adequadas que forem aplicáveis.

Segundo dados apresentados pela Comissão Interamericana:

Entre 1990 y 2007, más de 900 mujeres chilenas fallecieron por causa de homicidio, una gran mayoría víctimas de sus parejas o ex parejas. En Bahamas el feminicidio representó el $42 \%$ del total de los asesinatos en el año 2000, el $44 \%$ en 2001 y el $53 \%$ en 2002; en Costa Rica, llegó al $61 \%$ del total de homicidios de mujeres; en El Salvador, la mitad de los casos de violencia reportados por la prensa en 2005 acabaron en homicidios; en Puerto Rico, 31 mujeres fueron asesinadas como resultado de la violencia doméstica en el año 2004; y en Uruguay una mujer muere cada nueve días como resultado de la violencia doméstica. En todos los casos, mueren más mujeres a manos de sus parejas que a causa de la intervención de desconocidos. Estas cifras suscitan el rechazo generalizado de la población como lo demuestra la encuesta del Latinobarómetro 2006, en que el $90 \%$ de las personas 
encuestadas considera la violencia intrafamiliar como un grave problema (Lagos, 2007). ${ }^{33}$

Nesse contexto, uma das mudanças positivas na percepção da violência de gênero é o reconhecimento do feminicídio como um crime que já não é atenuado quando considerada a relação de proximidade entre o agressor e a vítima, como ocorria nos casos conhecidos como crimes de honra, caminhando-se para uma forma específica e agrava de crime contra as mulheres, precisamente por ser perpetrado por seus maridos, ex-maridos, companheiros, excompanheiros ou namorados.

A legislação penal brasileira, por meio da Lei $n^{\circ} 11.106$, de 28 de março de 2005, avançou nesse tema ao revogar o inciso VII, do artigo 109, do Código Penal, que previa como causa da extinção da punibilidade o casamento do agente com a vítima, nos crimes contra os costumes, definidos nos Capítulos I, II e III do Título VI da Parte Especial daquele Diploma.

No âmbito da jurisprudência da Corte Interamericana de Direitos Humanos, sobressai o Caso González y otras ("Campo Algodonero") Vs. México, oportunidade em que o Estado mexicano foi responsabilizado internacionalmente pela Corte por violações de direitos humanos em razão do desaparecimento e morte violenta de mulheres por questões de gênero.

Os fatos ocorreram na cidade de Juárez, lugar onde se desenvolvem diversas formas de delinquência organizada. Assim, desde 1993, existe um aumento de homicídios de mulheres influenciado por uma cultura de discriminação contra a mulher. No caso, uma estudante de 17 anos, uma trabalhadora de 20 anos e uma empregada doméstica de 15 anos, desapareçam entre os meses de setembro e outubro de 2001, tendo seus corpos sido encontrados em novembro daquele ano, com sinais de violência sexual, concluindo-se que as três mulheres estiveram privadas de sua liberdade antes de sua morte. Apesar dos recursos interpostos pelos familiares, não foram investigados nem responsabilizados os responsáveis.

Em sua sentença, a Corte reconheceu, que o Estado mexicano, em dois momentos, foi omisso ao prevenir a violência perpetrada contra as mulheres em razão de sua condição de gênero.

Sobre el primer momento - antes de la desaparición de las víctimas - la Corte considera que la falta de prevención de la desaparición no conlleva per se la responsabilidad internacional del Estado porque, a pesar de que éste tenía conocimiento de una situación de riesgo para las mujeres en Ciudad Juárez, no ha sido establecido que tenía conocimiento de un riesgo real e inmediato para las víctimas de este caso. Aunque el contexto en este caso y sus obligaciones internacionales le imponen al Estado una responsabilidad reforzada con respecto a la protección de mujeres en Ciudad Juárez, quienes se encontraban en una situación de vulnerabilidad, especialmente las mujeres jóvenes y humildes, no le imponen una ${ }^{33}$ Comissão Interamericana de Direitos Humanos. ¡Ni una más! El derecho a vivir una vida libre de violencia en América Latina y el Caribe. Outubro de 2007. Disponível em:

http://www.cidh.oas.org/women/Informe\%20Violencia\%20Contra\%20las\%20Mujeres\%20ECLAC\%202007.pdf 
responsabilidad ilimitada frente a cualquier hecho ilícito en contra de ellas. Finalmente, la Corte no puede sino hacer presente que la ausencia de una política general que se hubiera iniciado por lo menos en 1998 - cuando la CNDH advirtió del patrón de violencia contra la mujer en Ciudad Juárez-, es una falta del Estado en el cumplimiento general de su obligación de prevención. ${ }^{34}$

No segundo momento:

(...) antes del hallazgo de los cuerpos- el Estado, dado el contexto del caso, tuvo conocimiento de que existía un riesgo real e inmediato de que las víctimas fueran agredidas sexualmente, sometidas a vejámenes y asesinadas. La Corte considera que ante tal contexto surge un deber de debida diligencia estricta frente a denuncias de desaparición de mujeres, respecto a su búsqueda durante las primeras horas y los primeros días. Esta obligación de medio, al ser más estricta, exige la realización exhaustiva de actividades de búsqueda. En particular, es imprescindible la actuación pronta e inmediata de las autoridades policiales, fiscales y judiciales ordenando medidas oportunas y necesarias dirigidas a la determinación del paradero de las víctimas o el lugar donde puedan encontrarse privadas de libertad. Deben existir procedimientos adecuados para las denuncias y que éstas conlleven una investigación efectiva desde las primeras horas. Las autoridades deben presumir que la persona desaparecida está privada de libertad y sigue con vida hasta que se ponga fin a la incertidumbre sobre la suerte que ha corrido. 35

Concluiu a Corte que o Estado não demonstrou ter adotado normas ou implementado as medidas necessárias, conforme o artigo 2 da Convenção Americana e o artigo 7.c da Convenção de Belém do Pará, que permitiriam às autoridades oferecer uma respostas imediata e eficaz diante das denúncias de desaparecimento e de prevenir adequadamente a violência contra a mulher. Tampouco demonstrou ter adotado normas ou tomado medidas para que os funcionários responsáveis de receber as denúncias tivessem a capacidade e a sensibilidade para entender a gravidade do fenômeno da violência contra a mulher e a vontade para atuar de imediato. $^{36}$

Percebe-se, assim, que o Sistema Interamericano de Direitos Humanos tem precedentes quanto ao tema da violência contra as mulheres e aponta para a necessidade de os Estados-parte adotarem as medidas legislativas internas preventivas necessárias.

Relatório apresentado pelo Ministério da Justiça, por meio do Centro de Estudos sobre o Sistema de Justiça (CEJUS), da Secretaria de Reforma do Judiciário ${ }^{37}$, revelam as principais causas de homicídios praticados contra mulheres no Brasil, revelando fatos que se amoldam ao conceito de feminicídio e que exigiam uma atuação específica do Legislador pátrio.

Dentre suas conclusões o relatório perpassa sobre o tema do Direito Penal Simbólico:

\footnotetext{
${ }^{34}$ Corte Interamericana de Direitos Humanos. Caso González y otras ("Campo Algodonero”) Vs. México. Excepción Preliminar, Fondo, Reparaciones y Costas. Sentencia de 16 de noviembre de 2009. Serie C No.205, § 282.

${ }^{35}$ Idem. $\$ 283$.

${ }^{36}$ Ibidem. $\$ 285$.

${ }^{37}$ Disponível em: http://www.pnud.org.br/arquivos/publicacao_feminicidio.pdf. Acessado em 10/08/2015.
} 
Por um conjunto de características que compõem o senso comum e os discursos de justificação do direito criminal, cristalizou-se um modelo de pensamento que relaciona diretamente o grau de reprovabilidade de determinadas condutas e a estima social em relação ao objeto de proteção à gravidade da sanção penal. Se do ponto de vista da dissuasão pairam muitas dúvidas sobre a eficácia da criminalização de determinado comportamento, a criminalização, nesse contexto, vem exercendo um papel simbólico relevante na comunicação de que determinada conduta é reprovável. É esse enquadramento dos discursos sobre o crime e a pena, sedimentado em um contexto punitivista como a sociedade brasileira, que ajuda a explicar a estratégia de criminalização de condutas ou agravamento de penas quando se trata de sinalizar para a importância de determinada questão. É essa a aposta feita pelos movimentos sociais - como o movimento negro, feminista, LGBTI - quando demandam a criminalização de comportamentos como forma de obter reconhecimento de suas causas.

A positivação do feminicídio, a partir do prisma do Direito Internacional dos Direitos Humanos, revela que o mandado de criminalização da conduta atende aos compromissos internacionais assumidos pelo Brasil e se coaduna com a preocupação da Comissão Interamericana e da Corte Interamericana sobre o tema.

Apesar de ser objeto de crítica do Direito Penal Simbólico, é medida necessária e adequada para se prevenir o homicídio praticado em relação às mulheres, por razões da condição de sexo feminino, nos casos de violência doméstica e familiar e menosprezo ou discriminação à condição de mulher.

Afasta-se, também, qualquer alegação de inconstitucionalidade do dispositivo penal por conta de eventual violação da isonomia, pois, como já enfrentado pelo Supremo Tribunal Federal, na Ação Direta de Constitucionalidade $n^{\circ}$ 19, relatoria do Ministro Marco Aurélio, quando do questionamento da Lei Maria da Penha:

VIOLÊNCIA DOMÉSTICA - LEI N ${ }^{\circ} 11.340 / 06$ - GÊNEROS MASCULINO E
FEMININO - TRATAMENTO DIFERENCIADO. O artigo $1^{\circ}$ da Lei $\mathrm{n}^{\circ} 11.340 / 06$
surge, sob o ângulo do tratamento diferenciado entre os gêneros - mulher e homem
-, harmônica com a Constituição Federal, no que necessária a proteção ante as
peculiaridades física e moral da mulher e a cultura brasileira. COMPETÊNCIA -
VIOLÊNCIA DOMÉSTICA - LEI N $\mathrm{N}^{\circ} 11.340 / 06$ - JUIZADOS DE VIOLÊNCIA
DOMÉSTICA E FAMILIAR CONTRA A MULHER. O artigo 33 da Lei ${ }^{\circ}$
11.340/06, no que revela a conveniência de criação dos juizados de violência
doméstica e familiar contra a mulher, não implica usurpação da competência
normativa dos estados quanto à própria organização judiciária. VIOLÊNCIA
DOMÉSTICA E FAMILIAR CONTRA A MULHER - REGÊNCIA - LEI N $\mathrm{N}^{\circ}$
9.099/95 - AFASTAMENTO. O artigo 41 da Lei $\mathrm{n}^{\circ} 11.340 / 06$, a afastar, nos crimes
de violência doméstica contra a mulher, a Lei $\mathrm{n}^{\circ} 9.099 / 95$, mostra-se em
consonância com o disposto no $\S 8^{\circ}$ do artigo 226 da Carta da República, a prever a
obrigatoriedade de o Estado adotar mecanismos que coíbam a violência no âmbito
das relações familiares. ${ }^{38}$

Em seu voto, o relator deixa claro que a diferenciação legislativa guarda relações com os preceitos constitucionais e com as obrigações internacionais contraídas pelo Brasil acerca do tema.

\footnotetext{
${ }^{38}$ BRASIL. Supremo Tribunal Federal. ADC 19, Relator(a): Min. MARCO AURÉLIO, Tribunal Pleno, julgado em 09/02/2012, ACÓRDÃO ELETRÔNICO DJe-080 DIVULG 28-04-2014 PUBLIC 29-04-2014.
} 
Para frear a violência doméstica, não se revela desproporcional ou ilegítimo o uso do sexo como critério de diferenciação. A mulher é eminentemente vulnerável quando se trata de constrangimentos físicos, morais e psicológicos sofridos em âmbito privado. Não há dúvida sobre o histórico de discriminação e sujeição por ela enfrentado na esfera afetiva. As agressões sofridas são significativamente maiores do que as que acontecem contra homens em situação similar. Além disso, mesmo quando homens, eventualmente, sofrem violência doméstica, a prática não decorre de fatores culturais e sociais e da usual diferença de força física entre os gêneros.

Na seara internacional, a Lei Maria da Penha está em harmonia com a obrigação, assumida pelo Estado brasileiro, de incorporar, na legislação interna, as normas penais, civis e administrativas necessárias para prevenir, punir e erradicar a violência contra a mulher, tal como previsto no artigo $7^{\circ}$, item "c", da Convenção de Belém do Pará e em outros tratados internacionais ratificados pelo país.

Sob a óptica constitucional, a norma também é corolário da incidência do princípio da proibição de proteção insuficiente dos direitos fundamentais, na medida em que ao Estado compete a adoção dos meios imprescindíveis à efetiva concretização de preceitos contidos na Carta da República. A abstenção do Estado na promoção da igualdade de gêneros e a omissão no cumprimento, em maior ou menor extensão, de finalidade imposta pelo Diploma Maior implicam situação da maior gravidade político-jurídica, pois deixou claro o constituinte originário que, mediante inércia, pode o Estado brasileiro também contrariar o Diploma Maior.

A Lei Maria da Penha retirou da invisibilidade e do silêncio a vítima de hostilidades ocorridas na privacidade do lar e representou movimento legislativo claro no sentido de assegurar às mulheres agredidas o acesso efetivo à reparação, à proteção e à Justiça. A norma mitiga realidade de discriminação social e cultural que, enquanto existente no país, legitima a adoção de legislação compensatória a promover a igualdade material, sem restringir, de maneira desarrazoada, o direito das pessoas pertencentes ao gênero masculino. A dimensão objetiva dos direitos fundamentais, vale ressaltar, reclama providências na salvaguarda dos bens protegidos pela Lei Maior, quer materiais, quer jurídicos, sendo importante lembrar a proteção especial que merecem a família e todos os seus integrantes

Nesse contexto, a inclusão do feminicídio como qualificadora do crime de homicídio também se revela como medida necessária ao atual contexto jurídico brasileiro, e que, mesmo sendo alvo de críticas, pretende funcionar como instrumento de prevenção no combate à violência contra a mulher em razão de sua condição de sexo feminino.

\section{CONSIDERAÇÕES FINAIS}

No atual cenário, inúmeras infrações penais são praticadas no seio familiar, desde crimes contra a honra até o crime de homicídio, sendo as principais vítimas as mulheres. A impossibilidade de defesa dessas vítimas retrata a sua vulnerabilidade, aumentando a existência das denominadas cifras negras. Porém, a violência que essas mulheres sofrem não se restringe ao interior dos seus lares, pois muitas das vezes a simples condição de pertencerem ao sexo feminino acarreta a motivação dessa violência, o que despertou uma atenção especial por parte do legislador, inicialmente com a edição da Lei Maria da Penha, e, recentemente, com a inclusão da qualificadora do feminicídio.

No contexto do direito comparado restrito à América Latina, com destaque para o Código Penal Colombiano por ser exemplo de redação mais detalhada, em total conformidade 
com a definição de feminicídio, pois explicita o fim especial de agir do sujeito ativo, quando exige que o crime seja cometido pelo simples fato de a vítima ser mulher.

Em relação ao direito penal brasileiro, a alteração legislativa não se afasta do simbolismo penal. Este simbolismo surge toda vez que leis são editadas como forma de resposta ao clamor social.

Nesse sentido a qualificadora do feminicídio conduz a falsa percepção que antes da alteração legislativa, o homicídio de mulheres por questões de gênero não possuía tipificação no Código Penal, no entanto, a qualificadora do motivo torpe já supria essa omissão.

Assim, a função simbólica do direito penal, sustentada por Zaffaroni ${ }^{39}$, aplica-se ao feminicídio, pois o legislador fez questão de prever expressamente o denominado feminicídio no Código Penal, sem qualquer alteração na pena abstrata do homicídio qualificado, com o intuito de gerar uma sensação de que a mulher a partir de agora estaria protegida dessa conduta.

Por outro lado, essa crítica do simbolismo penal revela-se contestável quando avaliados os compromissos internacionais assumidos pela República Federativa do Brasil sobre a proteção e efetivação dos direitos humanos, protegendo e condenando qualquer forma de discriminação da mulher.

Nesse contexto, a inclusão do feminicídio como qualificadora do crime de homicídio também se revela como medida necessária ao atual contexto jurídico brasileiro, e que, mesmo sendo alvo de críticas, pretende funcionar como instrumento de prevenção no combate à violência contra a mulher em razão de sua condição de sexo feminino, reafirmando a função preventiva geral negativa da pena e cumprindo com as obrigações internacionais assumidas pelo Estado brasileiro.

\section{REFERÊNCIAS}

ALIMENA, Carla Marrone. A tentativa do impossivel: Feminismos e criminologias. Rio de Janeiro: Lumen Juris, 2010.

BARATTA, Alessandro. Criminologia crítica e crítica do direito penal: introdução à sociologia do direito penal. Tradução: Juarez Cirino dos Santos. 6. ${ }^{a}$ ed. Rio de Janeiro: Editora Revan, 2014.

BITENCOURT, Cezar Roberto. Tratado de Direito Penal: parte geral 1- 20. ${ }^{a}$ ed. São Paulo: Saraiva, 2014.

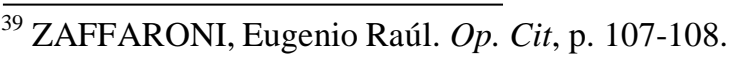


BRASIL. Supremo Tribunal Federal. RE 349703, Relator(a): Min. CARLOS BRITTO, Relator(a) p/ Acórdão: Min. GILMAR MENDES, Tribunal Pleno, julgado em 03/12/2008, DJe-104 DIVULG 04-06-2009 PUBLIC 05-06-2009 EMENT VOL-02363-04 PP-00675.

BREGA FILHO, Vladimir. Proibição do retrocesso social: o estado da arte em Portugal e no Brasil in Argumenta: Revista do Programa de Mestrado em Ciência Jurídica, da Universidade Estadual do Norte do Paraná - UENP. N. 19 (julho/dezembro) - Jacarezinho, 2013, p. 107.

CAPEZ, Fernando. Curso de direito penal, volume I, parte geral. 16. ${ }^{a}$ ed. São Paulo: Saraiva, 2012.

CHOUKR, Fauzi Hassan. Processo Penal de Emergência: Avaliação nos 20 anos de Vigência da Constituição de 1988. In Processo Penal e Democracia. Rio de Janeiro: Lumen Juris, 2009.

Comissão Interamericana de Direitos Humanos. ¡Ni una más! El derecho a vivir una vida libre de violencia en América Latina y el Caribe. Outubro de 2007.

Comissão Interamericana de Direitos Humanos. Relatório Anual 2000. Relatório no 54/01. Caso 12.051. Maria da Penha Maia Fernandes. Brasil. 4 de abril de 2001.

Corte Interamericana de Direitos Humanos. Caso González y otras ("Campo Algodonero") Vs. México. Excepción Preliminar, Fondo, Reparaciones y Costas. Sentencia de 16 de noviembre de 2009. Serie C No. 205.

Corte Interamericana de Direitos Humanos. Caso Damião Ximenes Lopes Vs. Brasil. Voto Separado do Juiz A. A. Cançado Trindade.

GUERRA, Sidney. Direitos humanos: curso elementar. São Paulo: Saraiva, 2013.

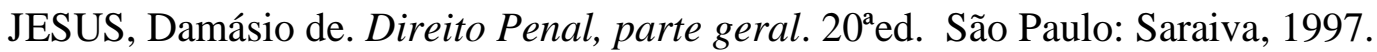

LIMA, Renato Brasileiro de. Manual de Processo Penal. 2.aed. Salvador, BA: Editora Juspodium, 2014.

MAXIMILIANO, Carlos. Hermenêutica e aplicação do direito. $20^{\mathrm{a}}$.ed. Rio de Janeiro: Forense, 2011.

MAZZUOLI, Valerio de Oliveira. Os sistemas de proteção dos direitos humanos. Valerio Mazzuoli; coordenação Alice Biachini, Luiz Flávio Gomes, William Terra de Oliveira. - São Paulo: Editora Revista dos Tribunais, 2011. - (Direito e ciências afins; v. 9).

PEGORER, Mayara Alice Souza. De Amélia a Maria da Penha: a evolução da legislação penal e das construções jurídicas na proteção dos direitos sexuais da mulher. Argumenta: Revista do Programa de Mestrado em Ciência Jurídica, da Universidade Estadual do Norte do Paraná UENP. N. 19 (julho/dezembro) - Jacarezinho, 2013. ISSN 1676-2800. 
MELLO, Celso de Albuquerque. O parágrafo $2^{o}$ do art. $5^{\circ}$ da Constituição Federal in TORRES, Ricardo Lobo (org.). Teoria dos direitos fundamentais. Rio de Janeiro: Renovar. NOVELINO, Marcelo. Direito Constitucional. 6. ed. Rio de Janeiro: Forense, 2012.

PIOVESAN, Flávia. Direitos humanos e direito constitucional internacional. 14. Ed. ver. E atual. São Paulo: Saraiva, 2013.

PRADO, Luiz Regis. Curso de direito penal, volume 2: parte especial. 9. ${ }^{a}$ ed. São Paulo: Editora Revista dos Tribunais, 2010.

QUEIROZ, Paulo. Sobre a função do juiz criminal na vigência de um direito penal simbólico. Boletim IBCCRIM. São Paulo, n. 74, p. 09, jan. 1999.

RAMOS, André de Carvalho. Teoria geral dos direitos humanos na ordem internacional. - 4. Ed. - São Paulo: Saraiva, 2014.

SARLET, Ingo Wolfgang. A eficácia dos direitos fundamentais. 11. Ed. ver. Atual. Porto Alegre: Livraria do Advogado Editora, 2012.

SERRANO MAÍLlO, Alfonso \& PRADO, Luiz Regis. Curso de criminologia. 2. ${ }^{a}$ ed. São Paulo: Editora Revista dos Tribunais, 2013.

ZAFFARONI, Eugenio Raúl. Manual de Direito Penal Brasileiro - Volume 1 - parte geral. $9^{a}$ ed., rev. e atual. São Paulo: Editora Revista dos Tribunais, 2011. 